\title{
ECLIPTA PROSTRATA (L.) L. A NEW ALIEN SPECIES IN CROATIAN FLORA
}

\author{
Mirjana Jeričević* \& Nebojša Jeričević \\ Medvinjak 558, 20275 Žrnovo, Hrvatska (*E-mail: labud93@gmail.com)
}

Jeričević, M. \& Jeričević, N.: Eclipta prostrata (L.) L. a new alien species in Croatian flora. Nat. Croat., Vol. 26, No. 1, 105-108, Zagreb, 2017.

During a field investigation on the island of Korčula, in 2016, Eclipta prostrata (Asteraceae) was found near the village of Smokvica, in the bay of Stiniva on moist sandy and rocky parts of the bay. Although this species has already been reported by many European countries it can be considered a new alien species for the Croatian flora.

Key words: alien species, Croatia, Eclipta prostrata, flora, island of Korčula

Jeričević, M. \& Jeričević, N.: Eclipta prostrata (L.) L., nova strana vrsta u hrvatskoj flori. Nat. Croat., Vol. 26, No. 1, 105-108, Zagreb, 2017.

Tijekom terenskih florističkih istraživanja na otoku Korčuli 2016. godine, vrsta Eclipta prostrata (Asteraceae) pronađena je na vlažnom pjeskovitom i kamenitom staništu uvale Stiniva nedaleko od Smokvice. To je prvi nalaz te vrste u Hrvatskoj.

Ključne riječi: strana vrsta, Hrvatska, Eclipta prostrata, flora, otok Korčula

\section{INTRODUCTION}

Eclipta prostrata (Asteraceae) is native to Asia but is widely naturalized around the world (HoLm et al., 1977). In most countries it is considered an increasing weed, especially in damp habitats; irrigated fields, river margins, rice fields, etc. (KRANTz et al., 1977). According to Tutin (1976) the species occurs also in European countries; Spain, Portugal and Italy. It has been recently recorded in Bulgaria (Tzonev, 2007), Greece (Arianoutsou et al., 2010), Albania (BARINA et al., 2013) and Montenegro (CAKović et al., 2014). It also appeared in Belgium, Cyprus, Romania, Turkey and Ukraine as a naturalized or casual alien (EURO+MED, 2006-2016). In general, in European countries the species grows in rice fields and other wet places (TuTIN, 1976). It seems that although E. prostrata prefers clayey soil with abundant moisture, it also has high salt adaptability (VARHNEY \& SHARMA, 1979).

Eclipta prostrata is a herbaceous annual plant (Fig. 1 and 2), with a prostrate, or sometimes erect, plant form. At the base of the main stem it develops several long stems, prostrate, rooting at the lower nodes. Stems are white-hairy, mostly purplish, branched. Leaves are opposite, acute at base, linear or oblong-lanceolate. Inflorescence is white, rounded, solitary or with two heads on unequal axillary peduncles. Seeds are dark, wedge-shaped, glabrous, pappus absent (JADHAV et al., 2009).

One Eclipta prostrata plant has the potential to produce over 17.000 seeds per plant in one growing season (PRоsтко, 2012). Plants can flower in five weeks after germination and produce seeds with no dormancy within 6 to 7 weeks that quickly germinate 


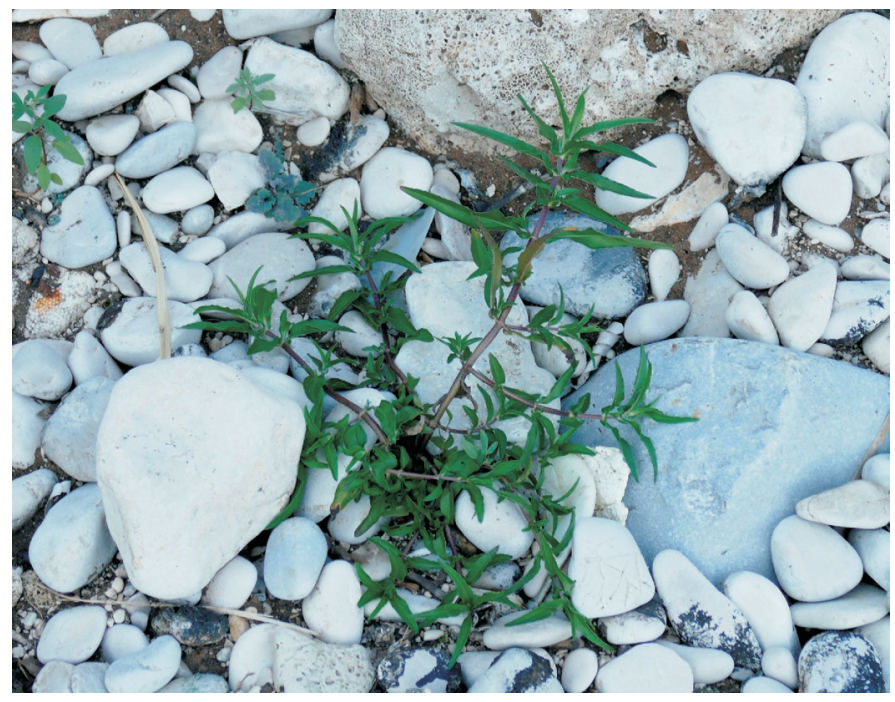

Fig. 1. Eclipta prostrata (L.) L. - habit on the island of Korčula (Photo by N. Jeričević).
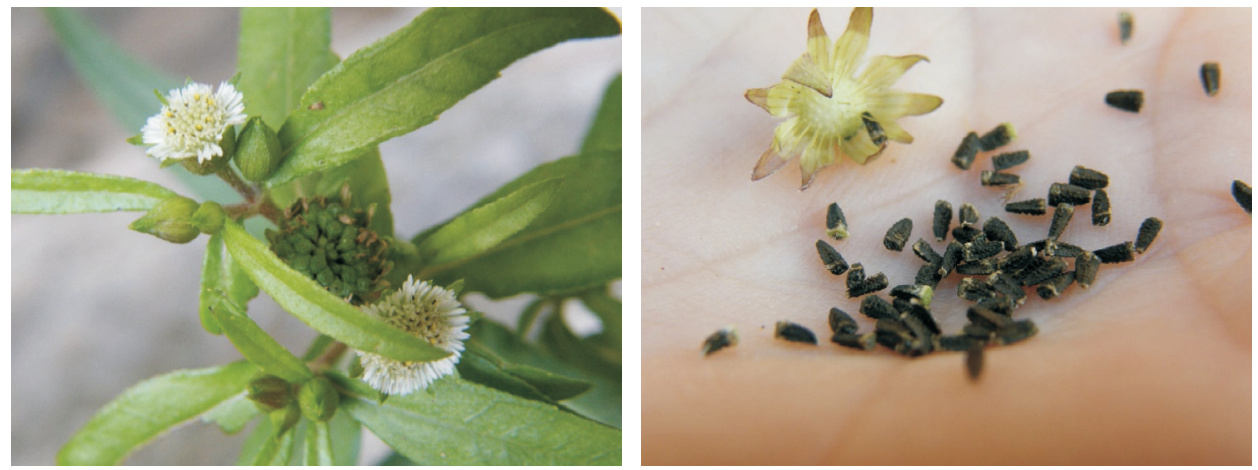

Fig. 2. Eclipta prostrata (L.) L. leaves and flowers, achene (Photo by N. Jeričević).

(GuptA, 1992). Eclipta prostrata can also reproduce vegetatively through adventitious rooting of nodes.

There are numerous studies about the medicinal and pharmaceutical uses of this plant in many countries, mainly in tropical and sub-tropical regions. The plant has been used for its analgesic, antimytotoxic, antihepatoxic, antibacterial, antioxidant, antihaemorrhagic, antihyperglycemic and immunomodulatory properties. Pharmacological activities have been seen in the metabolites and extracts of this plant (JADHAV et al., 2009). It is also reported to be an edible plant (KunKEL, 1984).

\section{MATERIALS AND METHODS}

Floristic investigations were carried out on the island of Korčula in August to November 2016. The location was geo-coded with the use of a GPS device, Garmin e-Trex 10. Identification of material was conducted according to Tutin et al. (1976) and PignatTi 

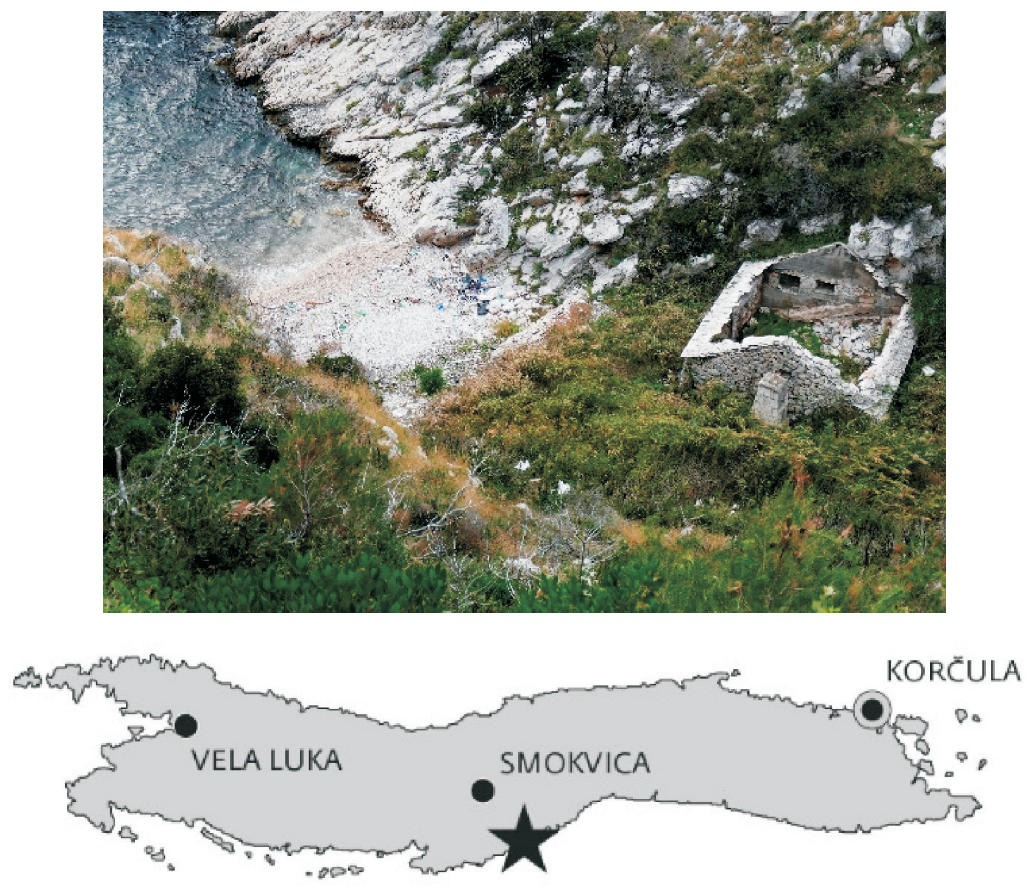

ISLAND OF KORČULA

Fig. 3. Finding site of Eclipta prostrata in the bay of Stiniva on island of Korčula (indicated by star on the map). (Photo by N. Jeričević).

(1982). Herbarium specimens of Eclipta prostrata (Herbarium ID: ZAGR 43638) have been deposited in the Herbarium ZAGR of the Faculty of Agriculture, University of Zagreb (Bogdanović (ed.) 2017).

\section{RESULTS}

Eclipta prostrata was found on the south slopes of the island of Korčula, near the village of Smokvica, in the bay of Stiniva $\left(42^{\circ} 54^{\prime} 22,87^{\prime \prime} \mathrm{N}, 16^{\circ} 54^{\prime} 38,82^{\prime \prime}\right.$ E) (Fig. 3). Just a few mature individuals were found. The plant is growing on the sandy and gravelly soils in the bay and it is highly exposed to saline conditions. The following species were also found in the locality: Bidens frondosa L., Calystegia sepium (L.) R. Br., Chenopodium album L., Euphorbia peplis L., Mercurialis annua L., Phragmites australis (Cav.) Trin. ex Steud., Senecio vulgaris L., Vitex agnus-castus L. and Solanum nigrum L.

We can assume that there is high possibility that the E. prostrata was transferred from the nearest known locality on Ulcinj bay in Montenegro to the island of Korčula by birds. Therefore we can expect that E. prostrata will be found in similar habitats in Croatia in the future, especially in river estuaries known to migratory birds as stopover habitats, such as the Neretva estuary.

The plant's blossoming and fruiting season on the island of Korčula appears to extend from August to November. 
We consider that further monitoring is needed to understand the impact of the species on local biodiversity.

Using existing proposals for Croatian standards and criteria for treating alien flora (Miтić et al., 2008), the invasion status for this species can be estimated as casual alien taxa (2.1.2.).

In summary, may the finding of E. prostrata in Croatian flora contribute to the knowledge of its chorology and ecology in the European countries, but also emphasises the further spreading of plant newcomers.

\section{ACKNOWLEDGEMENTS}

The authors would like to thank the two anonymous reviewers and Dr Nenad Jasprica for critical reading and very helpful suggestions. Also we thank Marija Šeparović for the support during the field research.

Received December 13, 2016

\section{REFERENCES}

Arianotsou, M., Bazos, I., Delipetrou, P. \& Kokkoris, Y., 2010: The alien flora of Greece: taxonomy, life traits and habitat preferences. Biological Invasions 12, 3525-3549.

BARINA, Z., RAKAJ, M. \& PifKó, D., 2013: Contributions to the flora of Albania, 4. Willdenowia 43, 165-184.

Caković, D., StešEvić, D., Vuksanović, S. \& TAN, K., 2014: Colchicum cupanii Guss. subsp. glossophyllum (Heldr.) Rouy, Datura innoxia Mill. and Eclipta prostrata (L.) L., new floristic records in Montenegro and Western Balkans. Acta Botanica Croatica 73 (1), 255-256, 2014.

EURO+MED, 2006-: Euro+Med PlantBase - the information resource for Euro-Mediterranean plant diversity. Published on the Internet http://ww2.bgbm.org/EuroPlusMed/ (2016).

Gupta, P.L., 1992: Seed germination study of Eclipta prostrata Linn. Advances in Plant Sciences 5, 187-198.

Holm, L. G., Plucknett, D. L., Pancho, J. V. \& Herberger, J. P., 1977: The World s Worst Weeds: Distribution and Biology. University Press of Hawaii, Honolulu.

Jadhav, V. M., Thorat, R. M., Kadam, V. J. \& Salaskar, K. P., 2009: Chemical composition, pharmacological activities of Eclipta alba. J. Pharm. Res., 2(8), 1129-1231.

KHAN, A. B. \& KHAN, A. A., 2008: Ethnomedicinal use of Eclipta prostrata Linn. Indian Journal of Traditional Knowledge 7, 316-320.

Krantz, J., Schmutterer, H. \& Koch, W. (eds.), 1977: Diseases, pests and weeds in tropical crops. Verlag Paul Parey, Berlin.

Kunkel, G., 1984: Plants for Human Consumption. Koeltz Scientific Books, Berlin.

Mitić, B., Boršić, I., Dujmović, I., Bogdanović, S., Milović, M., Cigić, P. \& Nikolić, T., 2008: Alien flora of Croatia: proposals for standards in terminology, criteria and related database. Natura Croatica 17 (2), 73-90.

Pignatti, S., 1982: Flora d' Italia, 3. Edagricole, Bologna.

Prostкo, P., 2012: Eclipta Identification Control in Peanut (C 869) CAES publications. University of Georgia, College of Agricultural end Environmental sciences 1-4.

Tutin, T. G., 1976: Eclypta L. in Tutin, T. G., Herwood, V., Burges, N. A., Moore, D. M., Valentine, D. H., Walters, S. M. \& Webb, D. A., (eds.). Flora Europaea 4, 141. University Press, Cambridge.

Tzonev, R., 2007: Eclipta prostrata (Asteraceae): a new alien species for the Bulgarian flora. Phytologia Balcanica 13, 79-80.

VARshney, S. P. \& Sharma, B. D., 1979. Responses of saline and non-saline populations of Eclipta alba to soil salinity. Canadian journal of plant science 59, 539-540. 